\title{
Brain mitochondrial injury induced by oxidative stress-related events is prevented by tamoxifen
}

\author{
Paula I. Moreira ${ }^{\mathrm{a}}$, José B. Custódio ${ }^{\mathrm{b}}$, Catarina R. Oliveira ${ }^{\mathrm{c}}$, Maria S. Santos ${ }^{\mathrm{a}, *}$ \\ ${ }^{a}$ Center for Neuroscience and Cell Biology of Coimbra, Department of Zoology - Faculty of Sciences and Technology, \\ University of Coimbra, 3004-517 Coimbra, Portugal \\ ${ }^{\mathrm{b}}$ Center for Neuroscience and Cell Biology, Laboratory of Biochemistry - Faculty of Pharmacy, \\ University of Coimbra, 3004-517 Coimbra, Portugal \\ ${ }^{\mathrm{c}}$ Center for Neuroscience and Cell Biology, Institute of Biochemistry - Faculty of Medicine, \\ University of Coimbra, 3004-517 Coimbra, Portugal
}

Received 29 April 2004; received in revised form 23 September 2004; accepted 29 October 2004

\begin{abstract}
This study evaluated the effect of the synthetic, nonsteroidal antiestrogen drug tamoxifen on the function of brain mitochondria. We observed that tamoxifen concentrations above $30 \mathrm{nmol} / \mathrm{mg}$ protein induced a slight decrease on $\mathrm{RCR}$ and ADP/O ratio. However, only higher concentrations of tamoxifen ( $\geq 70 \mathrm{nmol} / \mathrm{mg}$ protein) affected the phosphorylative capacity of mitochondria. Those effects were characterized by a decrease on mitochondrial transmembrane potential $(\Delta \Psi \mathrm{m})$ and repolarization level and an increase on repolarization lag phase with a decrease in ATP levels. Moreover, our results also show that tamoxifen presented a potent capacity to inhibit hydrogen peroxide formation and reduced the extent of lipid peroxidation induced by the pro-oxidant pair ADP $/ \mathrm{Fe}^{2+}$. Tamoxifen also exerted some protection against mitochondrial permeability transition pore (MPT) opening, although in a smaller extension than that promoted by cyclosporin A, the specific inhibitor of the MPT. However, in the presence of tamoxifen plus cyclosporin A, the protection observed was significantly higher when compared with that induced by both agents alone. Furthermore, tamoxifen avoided the oxidation of thiol groups and GSH depletion promoted by $\mathrm{Ca}^{2+}$.

These results show that tamoxifen can afford protection against brain mitochondrial injury promoted by several oxidative stressrelated events such as hydrogen peroxide production, lipid peroxidation and the induction of the MPT. Since numerous neurodegenerative diseases are intimately related with mitochondrial dysfunction, future therapeutical strategies could be designed taking into account this protective role of tamoxifen.
\end{abstract}

(C) 2004 Elsevier Ltd. All rights reserved.

Keywords: Brain; Mitochondria; Neuroprotection; Oxidative stress; Tamoxifen

Abbreviations: CsA, cyclosporin A; $\Delta \Psi \mathrm{m}$, mitochondrial transmembrane potential; GSH, reduced glutathione; GSSG, oxidized glutathione; $\mathrm{MPP}^{+}$, 1-methyl-4-phenyl-pyridinium ion; MPT, mitochondrial permeability transition pore; $\mathrm{NAD}^{+}$, nicotinamide adenine dinucleotide ion; NADH, nicotinamide adenine dinucleotide; $\mathrm{OH}-$ TAM, hydroxytamoxifen; $\mathrm{NADP}^{+}$, nicotinamide adenine dinucleotide phosphate ion; NADPH, nicotinamide adenine dinucleotide phosphate; RCR, respiratory control ratio; TAM, tamoxifen; $\mathrm{TPP}^{+}$, tetraphenylphosphonium ion.

* Corresponding author. Tel.: +351 239 834729; fax: +351 239 835812.

E-mail address: mssantos@ci.uc.pt (M.S. Santos).

\section{Introduction}

The synthetic nonsteroidal antiestrogen drug tamoxifen (TAM) is widely used in the chemotherapy of breast cancer (Richardson, 1988) and has been proposed as a prophylactic agent against this disease. In humans, TAM is extensively metabolised to give 4-hydroxytamoxifen (OHTAM) and $\mathrm{N}$-desmethyltamoxifen (Fromson et al., 1973). Besides their chemopreventing function, TAM and OHTAM, which are extremely 
lipophilic (Custódio et al., 1991, 1993), induce multiple cellular effects, including antioxidant actions since they are strong intramembranous scavengers of peroxyl radicals (Custódio et al., 1994).

Tamoxifen can penetrate the blood-brain barrier and interact with several neuronal estrogen receptor-positive cell populations (Jordan et al., 1983). Mehta et al. (2003) observed that TAM dramatically reduced middle cerebral artery occlusion-induced ischemic damage of the affected cerebral hemisphere. The reduction of infarct size was primarily due to protection of two major structures, the cerebral cortex and striatum. In the same study, Laser Doppler analysis revealed that tamoxifen had no significant effect on cerebral blood flow either before or after ischemia, suggesting that tamoxifen protection is independent of cerebral blood flow changes. More recently tamoxifen has been shown to be markedly neuroprotective in rat models of reversible and permanent focal ischemia (Kimelberg et al., 2003; Feng et al., 2004). O'Neill and Brinton (2002) showed that both TAM and OHTAM attenuate the excitotoxic glutamate-induced intracellular $\mathrm{Ca}^{2+}$ rise. Furthermore, TAM suppresses the $\mathrm{HO}^{\circ}$ generation via dopamine efflux induced by $\mathrm{MPP}^{+}\left(\mathrm{Obata}^{2}\right.$ 2002). A recent study shows that OHTAM attenuates methamphetamine-induced nigrostriatal dopaminergic toxicity in intact and gonadetomized mice (Kuo et al., 2003). However, the mechanisms of TAM-mediated neuroprotection independently of estrogen receptors are not yet clarified.

Recently, it has become clear that mitochondria have a significant role to play not only in energy production, but also in cell death (Bossy-Wetzel and Green, 1999). A potentially central factor in cell death during neurodegeneration is the mitochondrial permeability transition pore (MPT) (Kim et al., 1999). The MPT is a phenomenon that is characterized by the opening of pores in the inner mitochondrial membrane and by its sensitivity to a very low concentration of cyclosporin A (CsA). $\mathrm{Ca}^{2+}$ and oxidative stress have long been known to favour the permeability transition (Zoratti and Szabo, 1995). The MPT possesses at least two redox-sensitive sites that increase the probability of opening after oxidation: (1) the "S-site", a dithiol in apparent redox equilibrium with matrix glutathione and (2) the "P-site", in apparent redox equilibrium with the pyridine nucleotides pool (Chernyak and Bernardi, 1996).

Previous studies indicate that TAM (Custódio et al., 1998) and OHTAM (Cardoso et al., 2002a) are potent inhibitors of the MPT in liver mitochondria. Hoyt et al. (2000) reported that TAM might be an inhibitor of the MPT in intact neurons. However, MPT phenomenon in intact neurons has proven difficult to establish since other cellular components may contribute to misinterpretations, such as calcineurin that is also inhibited by cyclosporin A (CsA), the specific inhibitor of MPT.
With these evidences, we decided to study the effect of TAM directly in isolated brain mitochondria. Our first task was the evaluation of the impact of increasing concentrations of TAM $(15,30,70,100 \mathrm{nmol} / \mathrm{mg}$ protein) on the respiratory chain and oxidative system. For that purpose we analysed the respiratory indexes (RCR and $\mathrm{ADP} / \mathrm{O}$ ), mitochondrial transmembrane potential $(\Delta \Psi \mathrm{m})$, repolarization level, repolarization lag phase and ATP levels. The second part of this study consisted in the evaluation of the protective effect of TAM against hydrogen peroxide production, lipid peroxidation and $\mathrm{Ca}^{2+}$-induced MPT. The lipid peroxidation was evaluated by analysing $\Delta \Psi \mathrm{m}$, TBARS formation and oxygen consumption while the induction of MPT was characterized by analysing the $\Delta \Psi \mathrm{m}$, calcium fluxes, GSH content and protein thiol groups oxidation.

\section{Materials and methods}

\subsection{Materials}

Tamoxifen and Protease type VIII (Subtilisin Carlsberg) were obtained from Sigma Chemical Co. (St. Louis, MO). Digitonin was obtained from Calbiochem (Merck Biosciences Ltd., Nottingham). All the other chemicals were of the highest grade of purity commercially available.

\subsection{Animals}

Male Wistar rats (3 months old) were housed in our animal colony (Laboratory Research Center, University Hospital, Coimbra, Portugal). They were maintained under controlled light (12 h day/night cycle) and humidity with free access to water (except in the fasting period) and powdered rodent chow (URF1-Charles River, France). Adhering to procedures approved by the Institutional Animal Care and Use Committee, the animals were sacrificed by cervical displacement and decapitation.

\subsection{Isolation of brain mitochondria}

Brain mitochondria were isolated from male Wistar by the method of Rosenthal et al. (1987), with slight modifications, using $0.02 \%$ digitonin to free mitochondria from the synaptosomal fraction. In brief, one rat is decapitated, and the whole brain minus the cerebellum was rapidly removed, washed, minced, and homogenised at $4{ }^{\circ} \mathrm{C}$ in $10 \mathrm{ml}$ of isolation medium $(225 \mathrm{mM}$ mannitol, $75 \mathrm{mM}$ sucrose, $5 \mathrm{mM}$ Hepes, $1 \mathrm{mM}$ EGTA, $1 \mathrm{mg} / \mathrm{ml}$ bovine serum albumin, $\mathrm{pH}$ 7.4) containing $5 \mathrm{mg}$ of the bacterial protease. Single brain homogenates were brought to $30 \mathrm{ml}$ and then centrifuged at $2500 \mathrm{rpm}$ (Sorvall RC-5B Refrigerated Superspeed Centrifuge) for 
$5 \mathrm{~min}$. Mitochondria were recovered from the supernatant by centrifugation at $10,000 \mathrm{rpm}$ for $8 \mathrm{~min}$. The pellet, including the fluffy synaptosomal layer, was resuspended in $10 \mathrm{ml}$ of the isolation medium containing $0.02 \%$ digitonin and centrifuged at $10,000 \mathrm{rpm}$ for $8 \mathrm{~min}$. The brown mitochondrial pellet without the synaptosomal layer was then resuspended again in $10 \mathrm{ml}$ of medium and recentrifuged at 10,000 rpm for $10 \mathrm{~min}$. The mitochondrial pellet was resuspended in $300 \mu \mathrm{l}$ of resuspension medium $(225 \mathrm{mM}$ mannitol, $75 \mathrm{mM}$ sucrose, $5 \mathrm{mM}$ Hepes, pH 7.4). Mitochondrial protein was determined by the biuret method calibrated with bovine serum albumin (Gornall et al., 1949).

\subsection{Mitochondrial respiration measurements}

Oxygen consumption of isolated mitochondria was monitored polarographically with a Clark oxygen electrode (Estabrook, 1967) connected to a suitable recorder in a $1 \mathrm{ml}$ thermostated water-jacketed closed chamber with magnetic stirring. The reactions were carried out at $30{ }^{\circ} \mathrm{C}$ in $1 \mathrm{ml}$ of the reaction medium (100 mM sucrose, $100 \mathrm{mM} \mathrm{KCl,} 2 \mathrm{mM} \mathrm{KH_{2 }} \mathrm{PO}_{4}, 5 \mathrm{mM}$ Hepes, $10 \mu \mathrm{M}$ EGTA, $2 \mu \mathrm{M}$ rotenone, $\mathrm{pH}$ 7.4) with $0.6 \mathrm{mg}$ protein. The isolates were incubated with TAM for $2 \mathrm{~min}$ before succinate addition.

\subsection{Membrane potential $(\Delta \Psi m)$ measurements}

The mitochondrial transmembrane potential was monitored by evaluating the transmembrane distribution of $\mathrm{TPP}^{+}$(tetraphenylphosphonium) with a $\mathrm{TPP}^{+}$selective electrode prepared according to Kamo et al. (1979) using an $\mathrm{Ag} / \mathrm{AgCl}_{2}$ electrode as reference.

Reactions were carried out in a chamber with magnetic stirring in $1 \mathrm{ml}$ of reaction medium supplemented with $3 \mu \mathrm{M} \mathrm{TPP}{ }^{+}$. The experiments were started by adding $5 \mathrm{mM}$ succinate to mitochondria in suspension at $0.6 \mathrm{mg}$ protein $/ \mathrm{ml}$. Membrane potential was estimated from the decrease of $\mathrm{TPP}^{+}$concentration in the reaction medium as described elsewhere (Moreno and Madeira, 1991). The isolates were incubated with TAM for 2 min before succinate addition. In the MPT experiments, after a steady-state distribution of $\mathrm{TPP}^{+}$ had been reached (ca. 2 min of recording), $\mathrm{Ca}^{2+}$ was added and $\Delta \Psi \mathrm{m}$ recorded. In the lipid peroxidation experiments, $100 \mathrm{mM} \mathrm{ADP} / 10 \mathrm{mM} \mathrm{Fe}{ }^{2+}$ were added 1 min after mitochondria energization.

\subsection{Analysis of ATP levels}

At the end of the $\Delta \Psi \mathrm{m}$ experiments, $250 \mu$ of each mitochondrial suspension were rapidly centrifuged at 14,000 rpm (Eppendorf Centrifuge 5415C) for $4 \mathrm{~min}$ with $0.3 \mathrm{M}$ perchloric acid. The supernatants were neutralised with $10 \mathrm{M} \mathrm{KOH}$ in $5 \mathrm{M}$ Tris and centrifuged at 14,000 rpm (Eppendorf Centrifuge 5415C) for $4 \mathrm{~min}$. The resulting supernatants were assayed for ATP by separation in a reverse-phase high performance liquid chromatography. The chromatography apparatus was a Beckman-System Gold, consisting of a 126 Binary Pump Model and 166 Variable UV detector controlled by a computer. The detection wavelength was $254 \mathrm{~nm}$, and the column was a Lichrospher 100 RP-18 $(5 \mu \mathrm{m})$ from Merck. An isocratic elution with $100 \mathrm{mM}$ phosphate buffer $\left(\mathrm{KH}_{2} \mathrm{PO}_{4}\right) \mathrm{pH} 6.5$ and $1.0 \%$ methanol was performed with a flow rate of $1 \mathrm{ml} / \mathrm{min}$. The required time for each analysis was $6 \mathrm{~min}$.

\subsection{Hydrogen peroxide production}

Hydrogen peroxide $\left(\mathrm{H}_{2} \mathrm{O}_{2}\right)$ production was measured fluorimetrically using a modification of the method described by Barja (1999). Briefly, mitochondria were incubated at $30{ }^{\circ} \mathrm{C}$ with $10 \mathrm{mM}$ succinate in $2 \mathrm{ml}$ of phosphate buffer, $\mathrm{pH}$ 7.4, containing $0.1 \mathrm{mM}$ EGTA, $5 \mathrm{mM} \mathrm{KH} \mathrm{KHO}_{4}, 3 \mathrm{mM} \mathrm{MgCl}, 145 \mathrm{mM} \mathrm{KCl}, 30 \mathrm{mM}$ Hepes, $0.1 \mathrm{mM}$ homovalinic acid and $6 \mathrm{U} / \mathrm{ml}$ horseradish peroxidase. The incubation was stopped at $15 \mathrm{~min}$ with $0.5 \mathrm{ml}$ of cold $2 \mathrm{M}$ glycine buffer containing $25 \mathrm{mM}$ EDTA and $\mathrm{NaOH}, \mathrm{pH} 12$. The fluorescence of supernatants was measured at $312 \mathrm{~nm}$ as excitation and $420 \mathrm{~nm}$ as emission wavelengths. The peroxide production was calculated using a standard curve of $\mathrm{H}_{2} \mathrm{O}_{2}$.

\subsection{Lipid peroxidation}

The extent of lipid peroxidation was evaluated by oxygen consumption using a Clark-type electrode (YSI Model 5331, Yellow Springs Inst.) in a closed glass chamber equipped with magnetic stirring, thermostated at $30{ }^{\circ} \mathrm{C}$, as described by Dinis et al. (1994). Reactions were started by the addition of $100 \mathrm{mM}$ ADP/10 mM $\mathrm{Fe}^{2+}$. The changes in $\mathrm{O}_{2}$ tension were recorded in a potentiometric chart recorder and the oxygen consumption calculated assuming an oxygen concentration of $236 \mathrm{nmol} \mathrm{O}_{2} / \mathrm{ml}$. TAM was introduced in the incubation medium, containing mitochondria, $2 \mathrm{~min}$ before the addition of $\mathrm{ADP} / \mathrm{Fe}^{2+}$.

Lipid peroxidation was also determined by measuring thiobarbituric acid reactive substances (TBARS), using the thiobarbituric acid assay (TBA), according to a modified procedure described by Ernster and Nordenbrand (1967). The amount of TBARS formed was calculated using a molar coefficient of $1.56 \times$ $10^{5} \mathrm{~mol}^{-1} \mathrm{~cm}^{-1}$ and expressed as nmol TBARS/mg protein.

\subsection{Mitochondrial calcium fluxes}

Mitochondrial calcium fluxes were measured by monitoring the changes in $\mathrm{Ca}^{2+}$ concentration in the 
reaction medium using a calcium-selective electrode according to previously described procedures (Moreno and Madeira, 1991). The reactions were conducted in an open vessel with magnetic stirring in $1 \mathrm{ml}$ of the reaction medium. Mitochondria $(0.8 \mathrm{mg} / \mathrm{ml})$ were energized with $5 \mathrm{mM}$ succinate after $1 \mathrm{~min}$ of $\mathrm{Ca}^{2+}$ addition. $30 \mathrm{nmol}$ $\mathrm{TAM} / \mathrm{mg}$ protein, $0.85 \mu \mathrm{M}$ CsA and $2 \mu \mathrm{g} / \mathrm{ml}$ oligomycin plus $1 \mathrm{mM}$ ADP were added to the reaction medium 2 min prior to $\mathrm{Ca}^{2+}$ addition. In CsA plus TAM condition, CsA was added after mitochondria energization.

\subsection{Mitochondrial GSH content}

GSH was determined with fluorescence detection after reaction of the supernatant of the $\mathrm{H}_{3} \mathrm{PO}_{4} /$ EDTA$\mathrm{NaH}_{2} \mathrm{PO}_{4}$ deproteinized mitochondria solution with $o$ phthalaldehyde (OPT), pH 8.0, according to Hissin and Hilf (1976). In brief, at the end of the $\Delta \Psi \mathrm{m}$ experiments, $500 \mu$ of each mitochondrial suspension were rapidly centrifuged at $7000 \mathrm{rpm}$ for $5 \mathrm{~min}$. The pellets resuspended with $1.5 \mathrm{ml}$ phosphate buffer $\left(100 \mathrm{mM} \mathrm{NaH}_{2}\right.$ $\mathrm{PO}_{4}, 5 \mathrm{mM}$ EDTA, pH 8.0) and $500 \mu 1 \mathrm{H}_{3} \mathrm{PO}_{4} 4.5 \%$ were centrifuged at 50,000 rpm (Beckman, TL-100 Ultracentrifuge) for $30 \mathrm{~min}$. The supernatant $(100 \mu \mathrm{l})$ was added to $1.8 \mathrm{ml}$ phosphate buffer and $100 \mu \mathrm{l}$ OPT. After thorough mixing and incubation at room temperature for $15 \mathrm{~min}$, the solution was transferred to a quartz cuvette and the fluorescence was measured at $420 \mathrm{~nm}$. The GSH content was determined from comparisons with a linear glutathione standard curve.

\subsection{Mitochondrial thiol oxidation}

A variation of Ellman's method was used to determine the mitochondrial content in protein thiol groups (Riddles et al., 1983). At the end of the $\Delta \Psi \mathrm{m}$ experiments, $750 \mu 1$ of each mitochondrial suspension were frozen and thawed three times and, then, $750 \mu 1$ of sulphosalicilic acid $4 \%$ were added. The samples were submitted to centrifugation at 30,000 rpm (Beckman, TL-100 Ultracentrifuge) for $10 \mathrm{~min}$ at $4{ }^{\circ} \mathrm{C}$. The supernatant was removed and the pellet was suspended in $1.5 \mathrm{ml}$ of phosphate buffer $100 \mathrm{mM}, \mathrm{pH}$. The suspension was sonicated and diluted to $2.6 \mathrm{ml}$ in phosphate buffer medium containing $385 \mu \mathrm{M} 5,5^{\prime}$ dithio-bis-(2-nitobenzoic acid). After $10 \mathrm{~min}$ of reaction, the absorption was measured at $412 \mathrm{~nm}$ and the results expressed as percentage of control.

\subsection{Statistical analysis}

Results are presented as mean (\% of control/ peroxidation) \pm SEM of the indicated number of experiments. Statistical significance was determined using the one-way ANOVA test for multiple comparisons, followed by the post hoc Tukey-Kramer test.

\section{Results}

\subsection{Effect of TAM on brain mitochondria respiration}

Respiratory control ratio (RCR) is the ratio between mitochondrial respiration states 3 (consumption of oxygen in the presence of substrate and ADP) and 4 (consumption of oxygen after ADP has been consumed). Although $15 \mathrm{nmol} \mathrm{TAM} / \mathrm{mg}$ protein did not affect $\mathrm{RCR}, 30$ and $70 \mathrm{nmol} \mathrm{TAM} / \mathrm{mg}$ protein induced a similar decrease $(21.12 \pm 1.91 \%$ and $23.69 \pm 0.34 \%$, respectively) when compared with the control condition $(98.39 \pm 2.37 \%=3.1 \pm 0.07)$. However, $100 \mathrm{nmol}$ $\mathrm{TAM} / \mathrm{mg}$ protein induced a decrease on RCR when compared with the control condition $(44.2 \pm 0.05 \%)$ as well as when compared with $15(38.21 \pm 4.08 \%), 30$ $(23.08 \pm 1.86 \%)$ and $70 \mathrm{nmol} \mathrm{TAM} / \mathrm{mg}$ protein $(20.51 \pm 0.39 \%)$ conditions (Fig. 1). ADP/O ratio, an indicator of oxidative phosphorylation efficiency, is expressed by the ratio between the amount of ADP added and the oxygen consumed during the respiratory state 3 . Compared with the control condition $(99.57 \pm 1.76 \%=1.73 \pm 0.1 \mathrm{nmol} \mathrm{ADP} / \mathrm{nAtg} \mathrm{O})$, $\mathrm{ADP} / \mathrm{O}$ ratio was significantly decreased by $70(9.57 \pm$ $0.24 \%)$ or $100 \mathrm{nmol} \mathrm{TAM} / \mathrm{mg}$ protein $(13.19 \pm 0.23 \%)$ (Fig. 1).

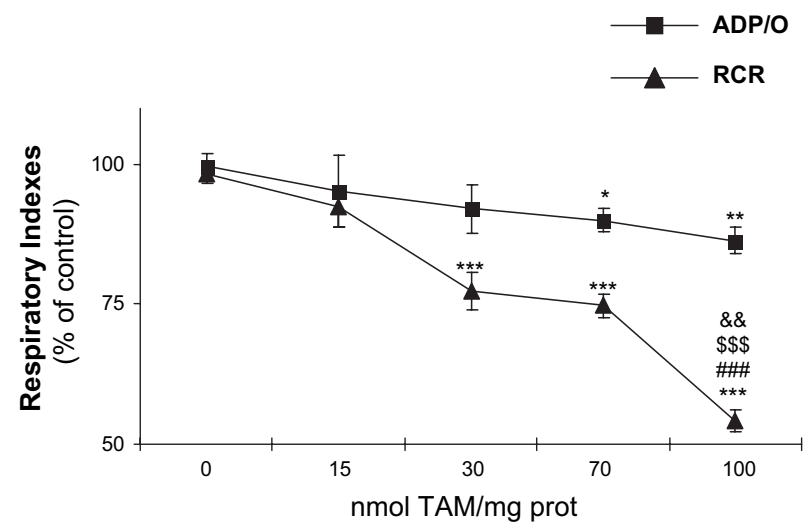

Fig. 1. Effect of TAM on respiratory indexes (RCR and ADP/O ratio) of brain mitochondria. Freshly isolated brain mitochondria $(0.6 \mathrm{mg})$ in $1 \mathrm{ml}$ of the standard medium were energized with $5 \mathrm{mM}$ succinate. Isolates were incubated with TAM for $2 \mathrm{~min}$, at $30^{\circ} \mathrm{C}$, before mitochondria energization. Results are presented as mean \pm SEM of six independent experiments. ${ }^{* * *} p<0.001 ; * * p<0.01 ; * p<0.05$, when compared with mitochondria in control condition. $\# \# \# p<0.001$, when compared with mitochondria incubated with $15 \mathrm{nmol} \mathrm{TAM} / \mathrm{mg}$ protein. $\$ \$ \$ p<0.001$, when compared with mitochondria incubated with $30 \mathrm{nmol} \mathrm{TAM} / \mathrm{mg}$ protein. $\& \& p<0.01$, when compared with mitochondria incubated with $70 \mathrm{nmol} \mathrm{TAM} / \mathrm{mg}$ protein. 
Table 1

Effect of TAM on mitochondrial transmembrane potential $(\Delta \Psi \mathrm{m})$, repolarization level, repolarization lag phase and ATP levels

\begin{tabular}{|c|c|c|c|c|c|}
\hline & $\begin{array}{l}\text { Control } \\
(n=6)\end{array}$ & $\begin{array}{l}15 \mathrm{nmol} \\
\text { TAM/mg prot } \\
(n=6)\end{array}$ & $\begin{array}{l}30 \mathrm{nmol} \\
\text { TAM/mg prot } \\
(n=6)\end{array}$ & $\begin{array}{l}70 \mathrm{nmol} \\
\text { TAM/mg prot } \\
(n=6)\end{array}$ & $\begin{array}{l}100 \mathrm{nmol} \\
\text { TAM/mg prot } \\
(n=6)\end{array}$ \\
\hline$\Delta \Psi \mathrm{m}$ & $101.5 \pm 1.3 \%$ & $99.5 \pm 1.1 \%$ & $98.5 \pm 0.9 \%$ & $95.2 \pm 1.4 \%$ & $85.7 \pm 3.1 \%^{* * *, \#, \$ \$, \&}$ \\
\hline $\begin{array}{l}\text { Repolarization } \\
\text { level }\end{array}$ & $104.9 \pm 1.7 \%$ & $98.7 \pm 2.8 \%$ & $97.1 \pm 1.2 \%$ & $91.6 \pm 1.7 \%$ & $68.5 \pm 7.0 \%^{* * *, \# \#, \$ \$ \$, \&}$ \\
\hline $\begin{array}{l}\text { Repolarization } \\
\text { lag phase }\end{array}$ & $99.8 \pm 0.9 \%$ & $120.6 \pm 2.0 \%$ & $131.4 \pm 8.7 \%$ & $177.4 \pm 12.5 \%$ & $406.2 \pm 64.9 \%{ }^{* * *, \# \# \#, \$ \$ \$, \& \&}$ \\
\hline ATP level & $100.0 \pm 2.1 \%$ & $126.4 \pm 11.2 \%$ & $100.6 \pm 10.3 \%$ & $94.7 \pm 10.0 \%$ & 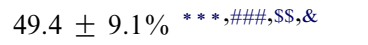 \\
\hline
\end{tabular}

Freshly isolated brain mitochondria $(0.6 \mathrm{mg})$ in $1 \mathrm{ml}$ of the reaction medium supplemented with $3 \mu \mathrm{M} \mathrm{TPP}{ }^{+}$and $2 \mu \mathrm{M}$ rotenone were energized with $5 \mathrm{mM}$ succinate. Isolates were pre-incubated with TAM for $2 \mathrm{~min}$, at $30^{\circ} \mathrm{C}$, before mitochondria energization.

*** $p<0.001$, when compared with control condition (mitochondria without TAM); \#\#\# $p<0.001$; \#\# $p<0.01$; \# $p<0.05$, when compared with mitochondria pre-incubated with $15 \mathrm{nmol} \mathrm{TAM} / \mathrm{mg}$ protein; $\$ \$ p<0.001 ; \$ \$ p<0.01$, when compared with mitochondria pre-incubated with $30 \mathrm{nmol} \mathrm{TAM} / \mathrm{mg}$ protein. \&\& $p<0.01 ; \& p<0.05$, when compared with mitochondria pre-incubated with $70 \mathrm{nmol} \mathrm{TAM} / \mathrm{mg}$ protein.

\subsection{Effect of TAM on brain mitochondrial transmem- brane potential $(\Delta \Psi \mathrm{m})$, repolarization level, repolarization lag phase and ATP levels}

The mitochondrial transmembrane potential $(\Delta \Psi \mathrm{m})$ is fundamental for the process of oxidative phosphorylation, the conversion of ADP to ATP via ATP synthase. Mitochondrial respiratory chain pumps $\mathrm{H}^{+}$ out of the mitochondrial matrix across the inner mitochondrial membrane. The $\mathrm{H}^{+}$gradient originates an electrochemical potential $(\Delta \mathrm{p})$ resulting in a $\mathrm{pH}$ $(\Delta \mathrm{pH})$ and a voltage gradient $(\Delta \Psi \mathrm{m})$ across the mitochondrial inner membrane. As shown in Table 1, only the presence of $100 \mathrm{nmol} \mathrm{TAM} / \mathrm{mg}$ protein induced a significant decrease on $\Delta \Psi \mathrm{m}$ and repolarization level (capacity of mitochondria to re-establish the $\Delta \Psi \mathrm{m}$, after ADP phosphorylation) when compared with all the other conditions tested (Table 1). The absolute values of $\Delta \Psi \mathrm{m}$ and repolarization level from the control condition are $-180.6 \pm 1.73 \mathrm{mV}$ and $-160.1 \pm 1.03 \mathrm{mV}$, respectively. Accordingly, the repolarization lag phase (time necessary for ADP phosphorylation) increased significantly in the presence of the highest TAM concentration tested. The absolute value of repolarization lag phase of control condition is $0.601 \pm 0.04 \mathrm{~min}$. Fig. 2 shows representative traces of the effect of

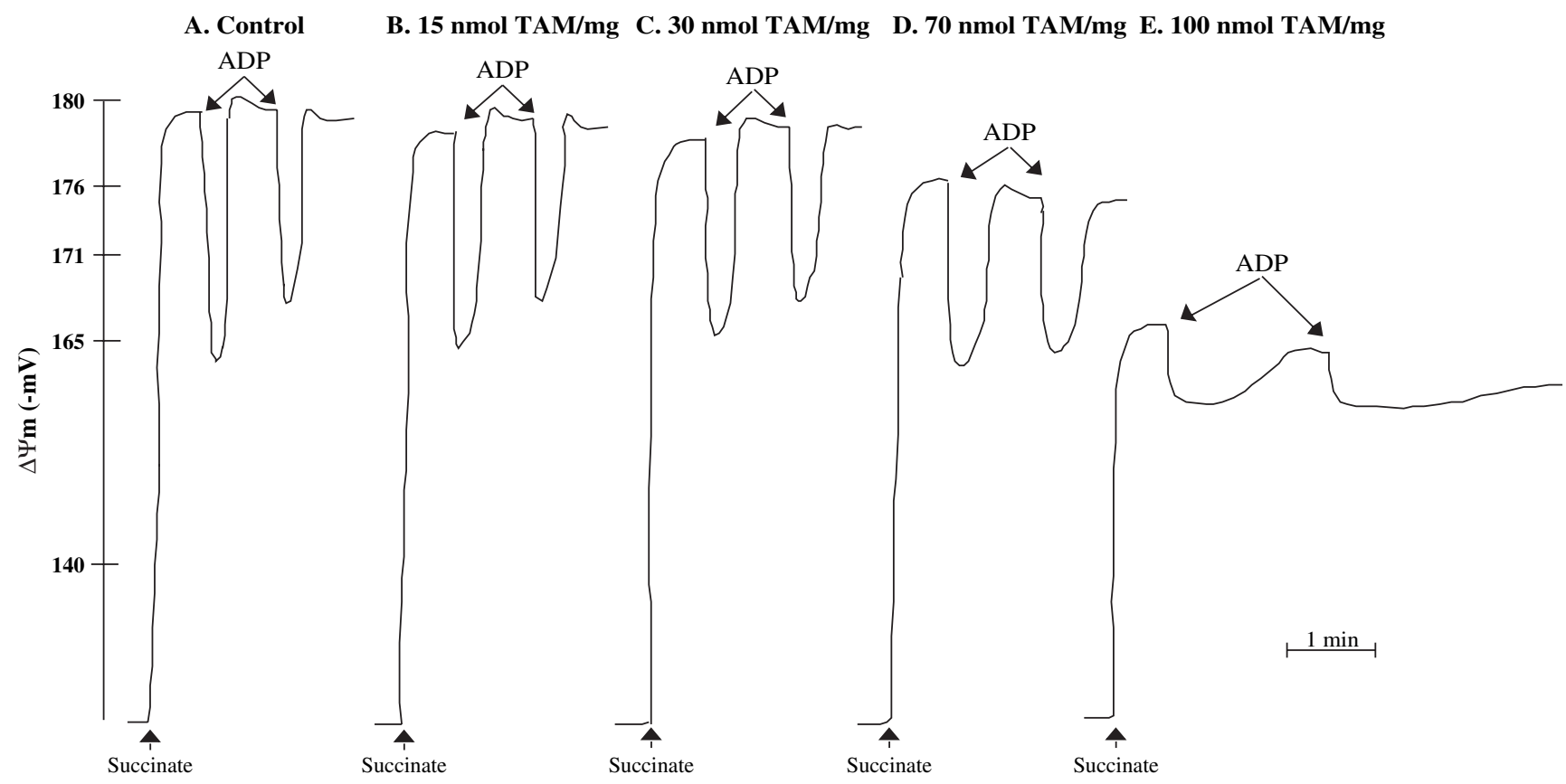

Fig. 2. Representative traces of the effect of TAM on $\Delta \Psi \mathrm{m}$, repolarization lag phase and repolarization level. Freshly isolated brain mitochondria $(0.6 \mathrm{mg})$ in $1 \mathrm{ml}$ of the standard medium supplemented with $3 \mu \mathrm{M} \mathrm{TPP}{ }^{+}$were energized with $5 \mathrm{mM}$ succinate. Isolates were pre-incubated with TAM for $2 \mathrm{~min}$, at $30^{\circ} \mathrm{C}$, before mitochondria energization. 
increasing concentrations $(15,30,70,100 \mathrm{nmol}$ TAM/ mg protein) of TAM on $\Delta \Psi \mathrm{m}$, repolarization level and repolarization lag phase.

The alterations observed in the oxidative phosphorylation system were reflected on the energetic levels. Table 1 shows that ATP levels decreased in the presence of $100 \mathrm{nmol} \mathrm{TAM} / \mathrm{mg}$ protein when compared with control condition $(50.57 \pm 7.09 \%), 15(76.97 \pm 2.06 \%)$, $30(51.17 \pm 1.17 \%)$ and $70 \mathrm{nmol} \mathrm{TAM} / \mathrm{mg}$ protein condition $(45.27 \pm 0.87 \%)$.

\subsection{Effect of TAM on hydrogen peroxide production}

The production of $\mathrm{H}_{2} \mathrm{O}_{2}$ by mitochondria gives an indication about the propensity of mitochondria to originate and/or exacerbate oxidative stress. The maximal production of $\mathrm{H}_{2} \mathrm{O}_{2}$ was $21.4 \pm 0.35 \mathrm{nmol} / \mathrm{mg}$ protein $/ 15 \min (102.0 \pm 1.68 \%)$. We observed that all the concentrations of TAM tested, $8.5(55.70 \pm 11.54 \%), 15$ $(35.29 \pm 5.31 \%), 3(23.76 \pm 6.67 \%)$ and $70 \mathrm{nmol} / \mathrm{mg}$ protein $(11.62 \pm 13.55 \%)$ reduced the production of $\mathrm{H}_{2} \mathrm{O}_{2}$ when compared with the condition of maximal production (Fig. 3).

\subsection{Effect of TAM on lipid peroxidation: oxygen consumption, TBARS formation and mitochondrial transmembrane potential $(\Delta \Psi \mathrm{m})$}

The oxygen consumption and TBARS assay were used to determine the level of lipid peroxidation induced by

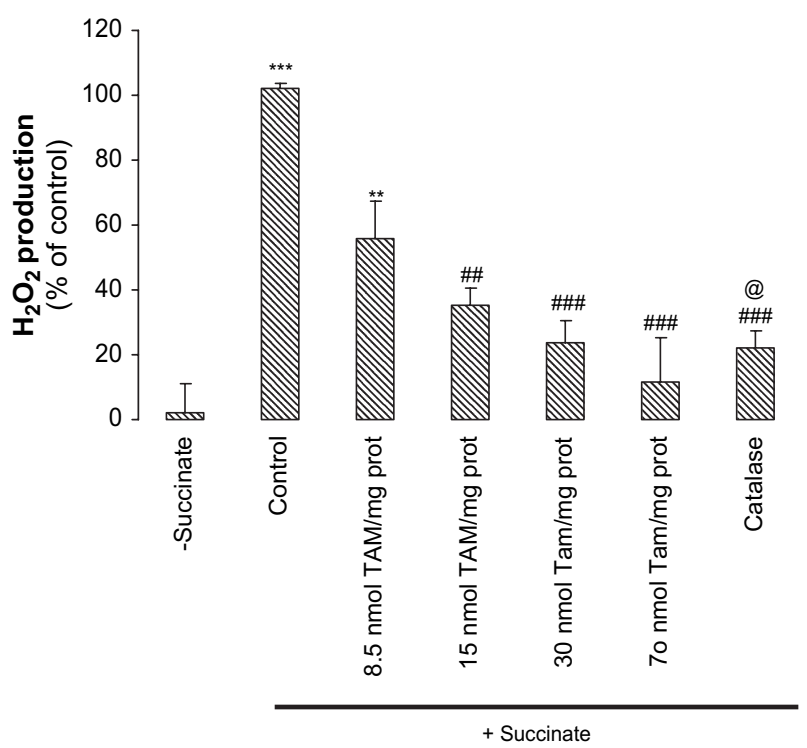

Fig. 3. Effect of TAM on hydrogen peroxide production. Brain mitochondria were incubated under standard conditions as described in Section 2. Results are presented as mean \pm SEM of four independent experiments. $* * * p<0.001 ; * * p<0.01$ when compared with basal production of $\mathrm{H}_{2} \mathrm{O}_{2}$ (mitochondria in the absence of substrate). $\# \# \#<0.001 ; \# \# p<0.01$, when compared with control condition (mitochondria in the presence of substrate) @p $<0.05$, when compared with mitochondria incubated with $70 \mathrm{nmol} \mathrm{TAM} / \mathrm{mg}$ protein.
$\mathrm{ADP} / \mathrm{Fe}^{2+}$. The maximal values of oxygen consumption (Fig. 4A) and TBARS formation (Fig. 4B), observed at 6 and $15 \mathrm{~min}$ of peroxidation, respectively, were $172.8 \pm 23.79 \mathrm{nmol} \mathrm{O}_{2} / \mathrm{mg}$ protein $(100.0 \pm 3.39 \%)$ and $29.70 \pm 1.27 \mathrm{nmol}$ TBARS/mg protein $(100.1 \pm$ $4.28 \%$ ). Concentrations of TAM above $8.5 \mathrm{nmol}$ $\mathrm{TAM} / \mathrm{mg}$ reduce the extent of lipid peroxidation and this protection was concentration-dependent (Fig. 4A, B).

The $\Delta \Psi \mathrm{m}$ is an important indicator of the mitochondrial membrane integrity. Fig. $4 \mathrm{C}$ shows that in the presence of $\mathrm{ADP} / \mathrm{Fe}^{2+}, \Delta \Psi \mathrm{m}$ was gradually lost indicating an impairment of mitochondria. However, the presence of $30 \mathrm{nmol} \mathrm{TAM} / \mathrm{mg}$ protein avoided membrane injury induced by $\mathrm{ADP} / \mathrm{Fe}^{2+}$, which was reflected by the maintenance of $\Delta \Psi \mathrm{m}$ (similar profile to those of control condition).

\subsection{Effect of TAM on the mitochondrial permeability transition}

\subsection{1. $\Delta \Psi m$ and calcium fluxes}

The mitochondrial potential $(\Delta \Psi \mathrm{m})$ drop is a typical phenomenon that follows the induction of MPT. In control conditions (Fig. 5A), the addition of $5 \mathrm{mM}$ succinate produced an $\Delta \Psi \mathrm{m}$ of $\approx 180 \mathrm{mV}$ (negative inside mitochondria), corresponding to the respiratory state 4 . Then, the first pulse of $20 \mathrm{nmol} \mathrm{Ca}{ }^{2+} / \mathrm{mg}$ protein led to a rapid depolarization (decrease of $\Delta \Psi \mathrm{m}$ ) followed by a small repolarization (recover of $\Delta \Psi \mathrm{m}$ ). The depolarization was due to the entry of $\mathrm{Ca}^{2+}$ into the electronegative mitochondrial matrix, followed by the efflux of $\mathrm{H}^{+}$in an attempt to restore the $\Delta \Psi \mathrm{m}$. However, a second and third pulse of $20 \mathrm{nmol} \mathrm{Ca}^{2+} / \mathrm{mg}$ protein led to a total depolarization of mitochondria. Mitochondria can tolerate a certain amount of $\mathrm{Ca}^{2+}$, but ultimately their capacity to adapt to $\mathrm{Ca}^{2+}$ loads is overwhelmed and mitochondria depolarize completely due to a profound change in the inner membrane permeability. Since the mitochondrial collapse of $\Delta \Psi \mathrm{m}$, associated to $\mathrm{Ca}^{2+}$ overload, is related with MPT opening, experiments were performed to further confirm the induction of the MPT opening by studying the $\mathrm{Ca}^{2+}$ retention by energized mitochondria. Fig. 6 shows that isolated brain mitochondria incubated with $50 \mathrm{nmol}$ $\mathrm{Ca}^{2+} / \mathrm{mg}$ protein in the presence of $2 \mathrm{mM}$ phosphate and energized with succinate, rapidly accumulate $\mathrm{Ca}^{2+}$ from the medium and, after a slow release of some of the accumulated $\mathrm{Ca}^{2+}$, they were able to continue to accumulate $\mathrm{Ca}^{2+}$, thus retaining part of the $\mathrm{Ca}^{2+}$ present in the medium. In the presence of $100 \mathrm{nmol}$ $\mathrm{Ca}^{2+} / \mathrm{mg}$ protein mitochondria retained a large portion of this cation. However, in the presence of $150 \mathrm{nmol}$ $\mathrm{Ca}^{2+} / \mathrm{mg}$ protein mitochondria became unable to retain the accumulated $\mathrm{Ca}^{2+}$ due to MPT opening (Fig. 6).

These effects on calcium accumulation could be prevented in the presence of $0.85 \mu \mathrm{M}$ CsA and $1 \mathrm{mM}$ 
ADP plus $2 \mu \mathrm{g} / \mathrm{ml}$ oligomycin. Although both agents contributed for a higher capacity of mitochondria to accumulate $\mathrm{Ca}^{2+}$, the protection exerted by ADP plus oligomycin was more effective than that exerted by CsA (Fig. 6). The presence of $30 \mathrm{nmol} \mathrm{TAM} / \mathrm{mg}$ protein ( 2 min pre-incubation) exerted some protection against mitochondrial membrane depolarization and calcium release, by increasing the capacity of mitochondria to accumulate $\mathrm{Ca}^{2+}$ (Figs. 5B, 6B). Additionally, the

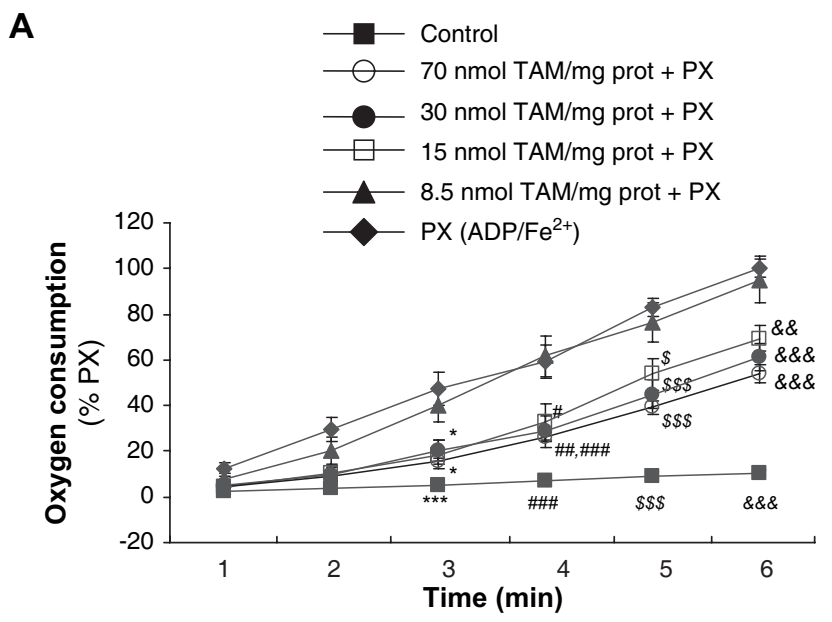

B
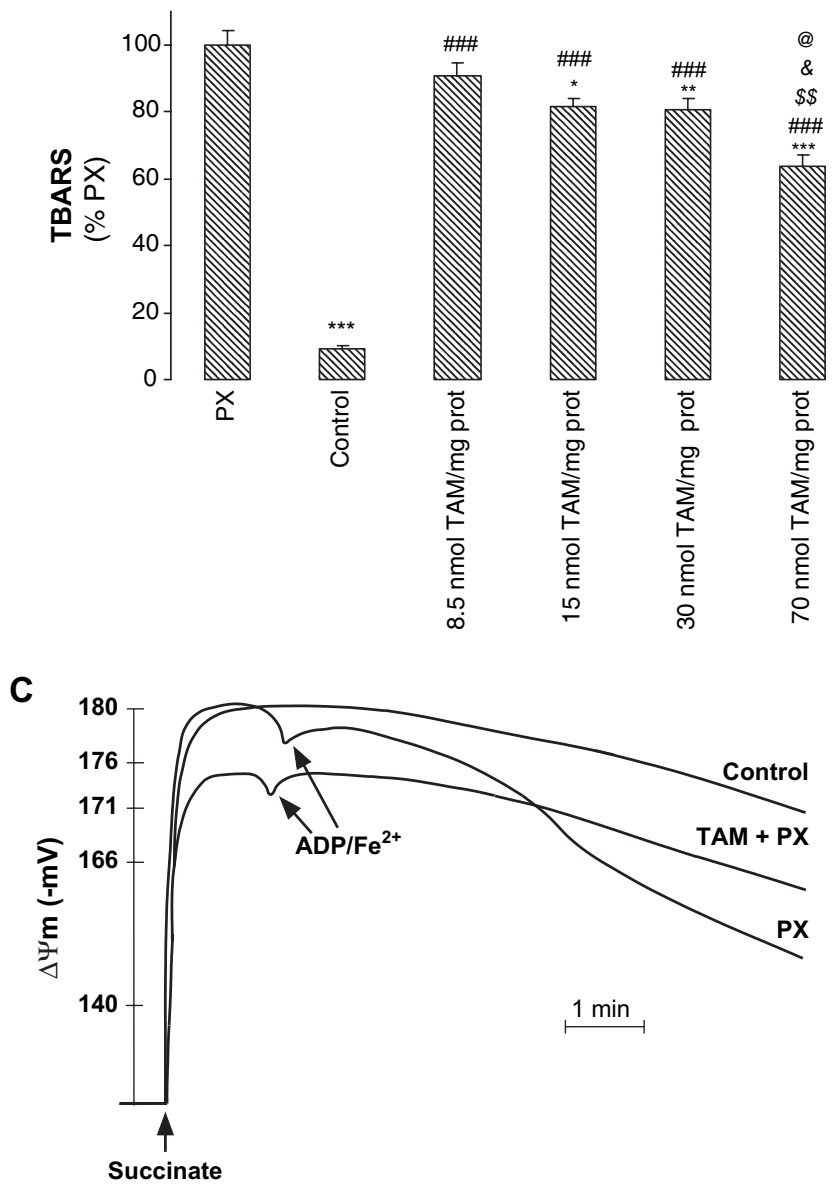

presence of $0.85 \mu \mathrm{M}$ cyclosporin $\mathrm{A}$ (CsA) (specific inhibitor of MPT) added 2 min prior to $\mathrm{Ca}^{2+}$, afforded a clear protection of mitochondria (Figs. 5C, 6). However, in the presence of both agents, $30 \mathrm{nmol}$ $\mathrm{TAM} / \mathrm{mg}$ protein and $0.85 \mu \mathrm{M} \mathrm{CsA}$, the capacity of mitochondria to accumulate $\mathrm{Ca}^{2+}$ increased significantly, mitochondria being more resistant to $\mathrm{Ca}^{2+}$ addition and, consequently, to MPT induction (Figs. 5D, 6B).

\subsubsection{Effect of TAM on the mitochondrial GSH content and protein thiol groups}

Opening of MPT is stimulated by the alteration of GSH and protein thiol redox status $(-\mathrm{SH} \rightarrow-\mathrm{SS}-)$. We observed that $60 \mathrm{nmol} \mathrm{Ca}{ }^{2+} / \mathrm{mg}$ protein induced a significant decrease on GSH content $(28.7 \% \pm 0.29)$ when compared with control condition (Fig. 7). The presence of $30 \mathrm{nmol} \mathrm{TAM} / \mathrm{mg}$ protein and/or $0.85 \mu \mathrm{M}$ CsA protect mitochondria against GSH release (Fig. 7).

Fig. 8 shows that $60 \mathrm{nmol} \mathrm{Ca}{ }^{2+} / \mathrm{mg}$ protein induces a small decrease of thiol groups. However, when mitochondria were pre-incubated with $30 \mathrm{nmol}$ TAM/ $\mathrm{mg}$ protein a significant increase on thiol groups occurred $(15.9 \pm 1.5 \%)$ when compared with mitochondria exposed to $60 \mathrm{nmol} \mathrm{Ca}{ }^{2+} / \mathrm{mg}$ protein (Fig. 8). The presence of $0.85 \mu \mathrm{M}$ CsA or $30 \mathrm{nmol} \mathrm{TAM} / \mathrm{mg}$ protein plus $0.85 \mu \mathrm{M}$ CsA protected against oxidation of thiol groups $(12.1 \pm 0.45 \%$ and $6.06 \pm 1.63 \%)$ when compared to mitochondria exposed to $60 \mathrm{nmol} \mathrm{Ca}^{2+} / \mathrm{mg}$ protein (Fig. 8).

\section{Discussion}

There is substantial evidence of impaired energy metabolism and mitochondrial dysfunction in the pathophysiology of chronic neurodegenerative disorders and in acute neurodegeneration caused by ischemia/ reperfusion injury (Fiskum et al., 1999). Several strategies have been developed in order to avoid or, at least, reduce mitochondrial dysfunction. One of those

Fig. 4. Effect of TAM on lipid peroxidation: oxygen consumption (A), TBARS formation (B) and $\Delta \Psi \mathrm{m}$ (C). Freshly isolated brain mitochondria were incubated at $0.6 \mathrm{mg}$ protein $/ \mathrm{ml}$ under standard conditions as described in Section 2. Isolates were pre-incubated with TAM for $2 \mathrm{~min}$, at $30{ }^{\circ} \mathrm{C}$, before the addition of $\mathrm{ADP} / \mathrm{Fe}^{2+}$. Results are presented as mean \pm SEM of four independent experiments. The traces are typical of three independent experiments. (4A) $* * * p<0.001 ; * p<0.05$ when compared with 3 min of peroxidation condition. \#\#\#p < 0.001; \#\#p <0.01; \#p<0.05, when compared with 4 min of peroxidation condition. $\$ \$ \$ p<0.001 ; \$ p<0.05$, when compared with $5 \mathrm{~min}$ of peroxidation condition. \&\&\&p<0.001; $\& \& p<0.01$, when compared with 6 min of peroxidation condition. (4B) $* * * p<0.001 ; * * p<0.01 ; * p<0.05$ when compared with the peroxidation condition. \#\#\#p<0.001, when compared with the control condition. $\$ \$ p<0.01$, when compared with $8.5 \mathrm{nmol} \mathrm{TAM} /$ $\mathrm{mg}$ protein condition. \& $p<0.05$, when compared with $15 \mathrm{nmol}$ $\mathrm{TAM} / \mathrm{mg}$ protein condition. @ $p<0.05$, when compared with $30 \mathrm{nmol}$ $\mathrm{TAM} / \mathrm{mg}$ protein condition. 
A. Control

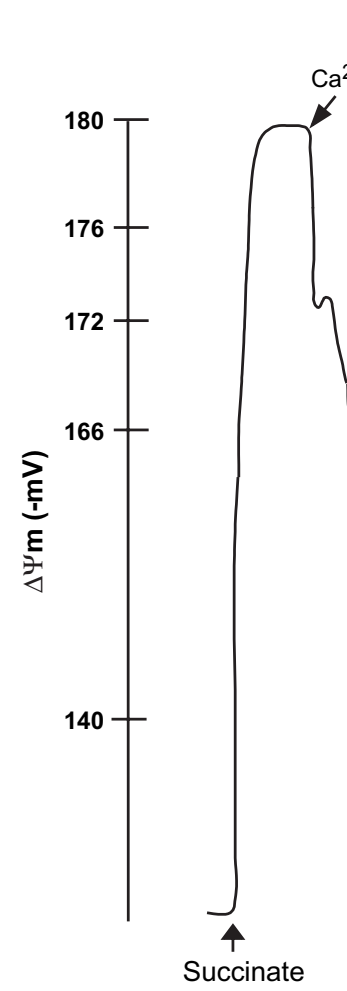

B. TAM

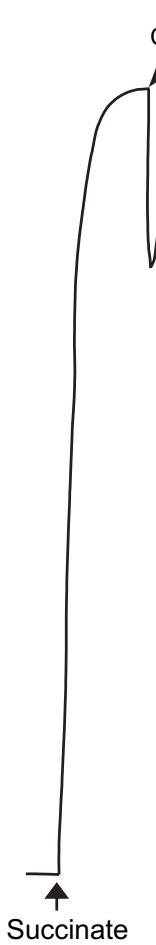

C. CsA

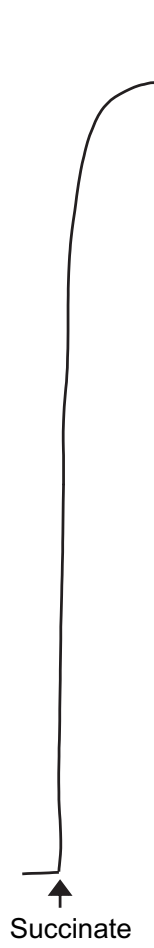

D. TAM + CsA

Fig. 5. Effect TAM on mitochondrial permeability transition pore induction: susceptibility to $\mathrm{Ca}^{2+}$ addition. Freshly isolated brain mitochondria $(0.6 \mathrm{mg})$ in $1 \mathrm{ml}$ of the standard medium supplemented with $3 \mu \mathrm{M} \mathrm{TPP}{ }^{+}$were energized with $5 \mathrm{mM}$ succinate. (A) Control condition; (B) $30 \mathrm{nmol}$ $\mathrm{TAM} / \mathrm{mg}$ protein; (C) $0.85 \mu \mathrm{M}$ CsA; (D) $30 \mathrm{nmol} \mathrm{TAM} / \mathrm{mg}$ protein plus $0.85 \mu \mathrm{M}$ CsA. Isolates were pre-incubated with TAM and/or CsA for $2 \mathrm{~min}$ before mitochondria energization. $\mathrm{Ca}^{2+}(3 \times 20 \mathrm{nmol} / \mathrm{mg}$ protein) was added $1.5 \mathrm{~min}$ after mitochondria energization. The traces are typical of three experiments.

strategies consists in the use of "protective" substances such as antioxidants. It has been reported that TAM and its more active metabolite OHTAM, due to their high partition into membranes, induce multiple cellular effects including antioxidant actions (Wiseman et al., 1990; Custódio et al., 1993, 1994) being strong intramembraneous scavengers of peroxyl radicals (Custódio et al., 1994).

However, and like other antioxidants, high TAM concentrations may adversely affect mitochondrial functions. We observed that TAM concentrations above $30 \mathrm{nmol} / \mathrm{mg}$ protein induced a slight decrease on RCR (Fig. 1), while ADP/O ratio was depressed with TAM concentrations of $70 \mathrm{nmol} / \mathrm{mg}$ protein (Fig. 1). However, the oxidative phosphorylation capacity was affected only for TAM concentrations equal or higher than $100 \mathrm{nmol} / \mathrm{mg}$ protein (Table 1). Recently Hoyt et al. (2000) reported that high concentrations of TAM cause mitochondrial depolarization and are neurotoxic for primary neuronal culture. Tuquet et al. (2000) observed that increasing concentrations of TAM act as both an uncoupling agent and a powerful inhibitor of electron transport in liver mitochondria. Recently, Cardoso et al. (2001, 2002b) reported that TAM and OHTAM decrease, in a concentration-dependent way, the RCR and
$\mathrm{ADP} / \mathrm{O}$ ratio of liver mitochondria. In the same studies, they observed that $20 \mathrm{nmol} \mathrm{TAM} / \mathrm{mg}$ protein affects the phosphorylation efficiency of liver mitochondria. The authors also observed that the partial collapse on $\Delta \Psi \mathrm{m}$ and the decrease on ADP phosphorylation parallel the increase on state 4 respiration indicating an uncoupling effect of these drugs on the oxidative phosphorylation system (Cardoso et al., 2001, 2002b). This uncoupling effect is due to a slight permeabilization to protons of the inner mitochondrial membrane (Cardoso et al., 2002b). Comparing the data from this study with those of Cardoso et al. $(2001,2002 b)$, it is clear that liver mitochondria are more susceptible to TAM than brain mitochondria since doses that do not affect brain are already deleterious to liver mitochondria. The existence of tissue-specific differences in mitochondria properties has been previously described (Moreira et al., 2002). The isolation procedure used in this study does not allow separation of mitochondria from different cell types meaning that "total" brain mitochondria could "hide" the response of a more vulnerable cell population. However, we must keep in mind that in the brain, a highly interconnected structure, the individual cells do not react simply as individuals when oxidative or toxic agents injure them. The different cell populations 
A
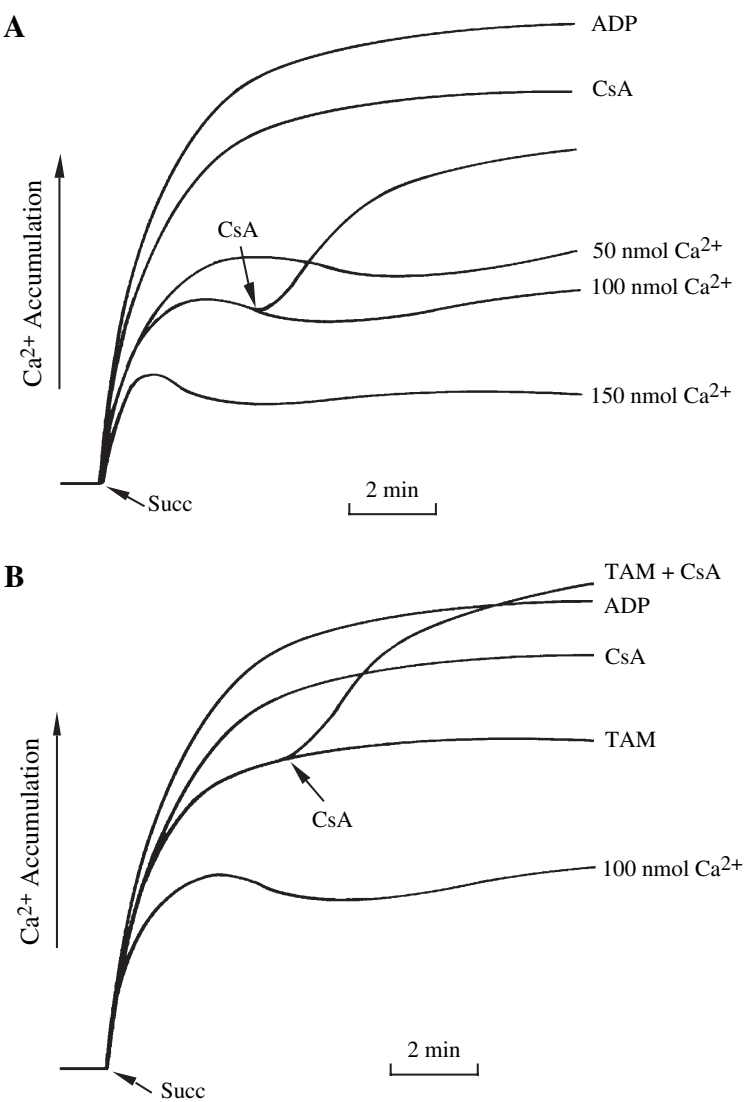

Fig. 6. Effect of TAM on calcium fluxes. Mitochondria were incubated at $0.6 \mathrm{mg}$ protein $/ \mathrm{ml}$ under standard conditions as described in Section 2. Standard medium was supplemented with $\mathrm{Ca}^{2+} 1 \mathrm{~min}$ before mitochondria energization with $5 \mathrm{mM}$ succinate. $30 \mathrm{nmol} \mathrm{TAM} / \mathrm{mg}$ protein, $0.85 \mu \mathrm{M}$ CsA and $2 \mu \mathrm{g} / \mathrm{ml}$ oligomycin plus $1 \mathrm{mM}$ ADP were added to the reaction medium 2 min prior $\mathrm{Ca}^{2+}$ addition. In CsA plus TAM condition, CsA was added after mitochondria energization. The uptake and release of sequestered $\mathrm{Ca}^{2+}$ by mitochondria were monitored as described in Section 2. The traces are typical of three experiments.

interact with each other, even at some distance from the site of the original toxin or injury. This means that simply looking at how an individual cell population is affected will not allow understanding how some cells survive better than we could expect. We need to look at how cells communicate with each other and how they may help each other to survive. A more appropriate level of description is to consider cooperative phenomena at the population level.

We also observed that TAM has a powerful antioxidant capacity, protecting brain mitochondria against $\mathrm{H}_{2} \mathrm{O}_{2}$ production and ADP/ $\mathrm{Fe}^{2+}$-induced lipid peroxidation. $\mathrm{H}_{2} \mathrm{O}_{2}$ is a stable, uncharged and freely diffusible reactive oxygen specie. The action of this molecule includes the oxidation of proteins and lipids, DNA strand breakage and base modification. Mitochondria are the major source of $\mathrm{H}_{2} \mathrm{O}_{2}$ production (Cadenas and Davies, 2000) and, at the same time, are also the targets of many of the detrimental effects of this reactive

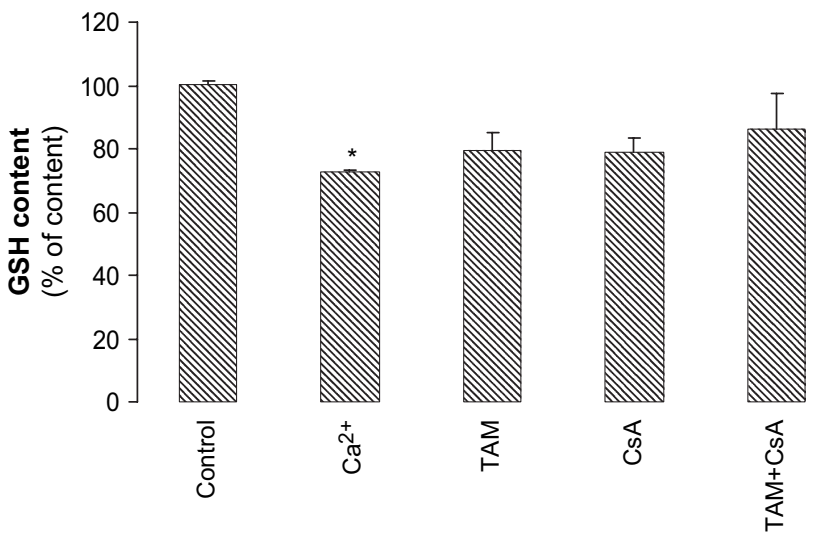

Fig. 7. Effect of TAM on mitochondrial GSH content. Freshly isolated brain mitochondria $(0.6 \mathrm{mg})$ in $1 \mathrm{ml}$ of the standard medium were energized with $5 \mathrm{mM}$ succinate. Isolates were pre-incubated with TAM and/or CsA for $2 \mathrm{~min}$, at $30{ }^{\circ} \mathrm{C}$, before mitochondria energization. $60 \mathrm{nmol} \mathrm{Ca}{ }^{2+} / \mathrm{mg}$ protein was added after mitochondria energization. Results are presented as mean \pm SEM of six independent experiments. ${ }^{*} p<0.05$, when compared with mitochondria in control condition.

molecule. Fig. 3 shows that TAM has a potent concentration-dependent capacity to prevent $\mathrm{H}_{2} \mathrm{O}_{2}$ production. This capacity of TAM could be extremely important in terms of brain disorders such as Alzheimer's disease. Of particular relevance to the role of $\mathrm{H}_{2} \mathrm{O}_{2}$ in Alzheimer's disease is the observation that amyloid $\beta$-peptide, which is a central element in this pathology (Hardy and Higgins, 1992), can itself generate $\mathrm{H}_{2} \mathrm{O}_{2}$ (Huang et al., 1999; Brzyska et al., 2001). A study from O'Neill et al. (2004) showed that raloxifene (estrogen receptor modulator) at low concentrations $(50 \mathrm{ng} / \mathrm{ml})$ induces a significant neuroprotection against $\beta$-amyloid-, $\mathrm{H}_{2} \mathrm{O}_{2^{-}}$and glutamate-induced toxicity. However, the

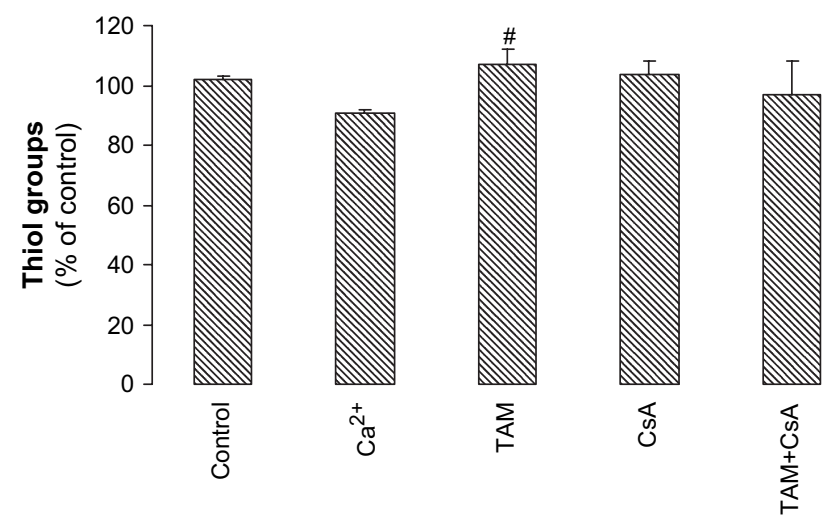

Fig. 8. Effect of TAM on mitochondrial protein thiol groups oxidation. Freshly isolated brain mitochondria $(0.6 \mathrm{mg})$ in $1 \mathrm{ml}$ of the standard medium were energized with $5 \mathrm{mM}$ succinate. Isolates were pre-incubated with TAM and/or CsA for $2 \mathrm{~min}$, at $30^{\circ} \mathrm{C}$, before mitochondria energization. Results are presented as mean \pm SEM of six independent experiments. $60 \mathrm{nmol} \mathrm{Ca}^{2+} / \mathrm{mg}$ protein was added after mitochondria energization. $\# p<0.05$, when compared with mitochondria exposed to $60 \mathrm{nmol} \mathrm{Ca}{ }^{2+} / \mathrm{mg}$ protein. 
same study showed that raloxifene exerts partial estrogen agonist action in the absence of $17 \beta$-estradiol whereas in its presence raloxifene exerted a mixed estrogen agonistantagonist effect. Similarly, Lei et al. (2003) found that estrogen and raloxifene can influence glial-mediated inflammatory pathways and possibly protect against age- and disease-related neuropathology.

Our results also show that TAM protects against lipid peroxidation (Fig. 4). It has been described that OHTAM, the principal metabolite of TAM, is a scavenger of peroxyl radicals in several cells and systems. OHTAM inhibits lipid peroxidation in sarcoplasmic reticulum membranes (Custódio et al., 1994), $\mathrm{Fe}^{2+}$ ascorbate-induced lipid peroxidation in rat liver microsomes (Wiseman et al., 1990) and $\mathrm{ADP} / \mathrm{Fe}^{2+}$-induced oxidation in brain mitochondria (Moreira et al., 2004). Furthermore, the ability of TAM and OHTAM to inhibit $\mathrm{Cu}^{2+}$-induced peroxidation of low-density lipoprotein has been suggested to contribute to the putative cardioprotective effects of these antiestrogens (Wiseman et al., 1993). Dubey et al. (1999) demonstrated that estrogen and tamoxifen metabolites protect smooth muscle cell membrane phospholipids against peroxidation via a non-estrogen receptor-dependent mechanism. There are, however, controversial reports stating that TAM and OHTAM are associated with intracellular oxidative stress (Duthie et al., 1995). These discrepancies can be due to differences in the concentrations of TAM and OHTAM and/or experimental models used. Indeed, some animal studies indicate the existence of dose-related biphasic effects of estradiol (Levesque and Di Paolo, 1993). Some effects are lost at higher concentrations (Levesque and Di Paolo, 1993), whereas others require high doses (Green et al., 1997). These dose-related effects could be taken as an advantage allowing the dissociation of the several activities exerted by the compound in the target tissue. It is possible that a similar picture occurs with antiestrogen compounds.

Although TAM is extensively metabolised in the liver (Fromson et al., 1973), it has been reported that in humans equal amounts of TAM and its metabolites are found in both normal brain tissue and cerebral metastasis (Lien et al., 1991) suggesting that in living organisms both TAM and OHTAM are involved in neuroprotection. Moreover, owing to its high hydrophobic character and partition into biological membranes (Custódio et al., 1991), the levels of TAM in humans are 10- to 60-fold higher in tissues than in plasma $(\approx 1 \mu \mathrm{M})$ (Lien et al., 1991). Therefore, the therapeutics with TAM may cause tissue concentrations similar to those used in this study. However, we also tested some concentrations higher than the physiological/pharmacological tissue concentrations of TAM to demonstrate that only extremely high doses of this drug affect brain mitochondrial function.
Since previous studies (Custódio et al., 1998; Hoyt et al., 2000; Cardoso et al., 2001) demonstrated the inhibitory effect of TAM on MPT induction, we decided to evaluate the effect of $30 \mathrm{nmol} \mathrm{TAM} / \mathrm{mg}$ protein on $\mathrm{Ca}^{2+}$-induced MPT of isolated brain mitochondria. This concentration of TAM was more effective against MPT opening when compared with lower concentrations of TAM tested (data not shown) and, as shown by our data, is not toxic to brain mitochondria. The MPT causes a non-selective permeabilization of the inner mitochondrial membrane typically promoted by the accumulation of excessive quantities of $\mathrm{Ca}^{2+}$ ions and stimulated by a variety of compounds or conditions (Zoratti and Szabo, 1995). In this study, the classic inductor $\mathrm{Ca}^{2+}$ was used to induce MPT opening (Figs. $5,6) . \mathrm{Ca}^{2+}$ uptake was concentration-dependent, with higher concentrations leading to a lower amount of $\mathrm{Ca}^{2+}$ being accumulated by mitochondria, indicating a continuous cycling of $\mathrm{Ca}^{2+}$ due to MPT induction. The pore opening allows the equilibration of ions and respiratory substrate between cytosol and mitochondrial matrix leading to a reduction on $\Delta \Psi \mathrm{m}$ (Bernardi et al., 1992) that is linked to depletion of GSH (Macho et al., 1997). Indeed, mitochondrial pore induction is intimately associated with GSH and protein thiol redox state (Le Quoc et al., 1976). Glutathione is the most abundant antioxidant in the cell. Its protective action is based on the oxidation of the thiol group of its cysteine residue, resulting in the formation of oxidized glutathione (GSSG); this is in turn, catalytically reduced back to the thiol form GSH by glutathione reductase (Meister and Anderson, 1983). Regeneration of GSH from GSSG occurs in mitochondrial matrix. Continued regeneration of GSH requires NADPH, which in turn requires transhydrogenation of $\mathrm{NADP}^{+}$and NADH. In this study, each experiment last for $4 \mathrm{~min}$, a period of time insufficient to induce any significant alteration in the elements involved in GSH regeneration. Furthermore, Custódio et al. (1998) showed that the loss of matrix GSH is attributed to its release to the medium since no GSSG was detected in any of the reactions and the total GSH levels (intra and extramitochondrial) did not change. So, the depletion of GSH was solely due to the efflux from the permeabilized mitochondria, which was prevented by cyclosporin A and tamoxifen. When protein thiol groups from the inner mitochondrial membrane are oxidized, the pore complex suffers conformational changes resulting in a large nonselective permeabilization of the mitochondrial membrane (Kowaltowski et al., 1998). Accordingly, a decrease on GSH content (Fig. 7) and thiol groups (Fig. 8) were observed in mitochondria exposed to $\mathrm{Ca}^{2+}$. The effect of $\mathrm{Ca}^{2+}$ on GSH content was more pronounced than the oxidation of thiol groups probably because a fraction of the GSH pool was used to prevent a drastic oxidation of the thiol groups. This fact may be 
interpreted as a rescue strategy in an attempt to inhibit or, at least, delay MPT induction.

The presence of $30 \mathrm{nmol} \mathrm{TAM} / \mathrm{mg}$ protein exerted some protection against $\mathrm{Ca}^{2+}$-induced MPT opening (Figs. 5B, 6B). Our data support the idea suggested by Hoyt et al. (2000) that TAM may be an inhibitor of the MPT in intact neurons. Furthermore, our results are consistent with the observations of Morkuniene et al. (2002) that OHTAM prevented calcium-induced loss of cytochrome $c$ from heart mitochondria. In our study, CsA does not give a total protection against MPT induction but increases the capacity of brain mitochondria to accumulate $\mathrm{Ca}^{2+}$ (Figs. 5C, 6). Simpson et al. (2002) observed that TAM exerted a CsA-like action on SH-SY5Y neuroblastoma mitochondria. Moreover, Custódio et al. (1998) observed that $20 \mathrm{nmol} \mathrm{TAM} / \mathrm{mg}$ protein cause a total inhibition of $\mathrm{Ca}^{2+}$-induced depolarization of succinate-energized liver mitochondria similar to that exerted by CsA. As referred above, due to tissue-specific differences in mitochondria pore properties (Moreira et al., 2002) the ability of both agents, TAM and CsA, to protect against MPT induction differs significantly between different types of mitochondria. The effect of CsA on the ability of brain mitochondria to accumulate $\mathrm{Ca}^{2+}$ was only moderate when compared with the effects described for CsA on muscle or liver mitochondria (Kristián et al., 2000; Moreira et al., 2002). Similar effects of CsA were also reported on cell lines (Murphy et al., 1996) and neuronal primary cultures (Dubinsky and Levi, 1998). Another study performed in a neuronal primary culture showed that mitochondrial depolarization induced by glutamate was partially inhibited by TAM (Hoyt et al., 2000). TAM per se was capable of protecting against GSH depletion (Fig. 7) and thiol oxidation (Fig. 8), being the protection of thiol groups more pronounced than that exerted by CsA. Custódio et al. (1998) also reported the inhibitory effect of TAM on GSH release. However, the most relevant finding was that $30 \mathrm{nmol} \mathrm{TAM} / \mathrm{mg}$ protein plus CsA exerted a higher protection against MPT opening (Figs. 5D, 6B) when compared with the protection exerted by each agent alone (Figs. 5B, C, 6). These results indicate that the effects of both agents are not additive, suggesting that they act at different places on pore complex. The most plausible hypothesis concerning MPT inhibition by CsA is that cyclophilin $\mathrm{D}$ binding to the matrix side of the MPT favours its opening and that CsA indirectly causes pore closure through unbinding of cyclophilin D after formation of the CsA-cyclophilin complex (Connern and Halestrap, 1996). In turn, MPT inhibition in brain mitochondria by TAM may be due to its antioxidant properties since this antiestrogen inhibits mitochondrial lipid peroxidation and protects against mitochondrial $\mathrm{H}_{2} \mathrm{O}_{2}$ production, thiol groups oxidation and GSH release.
These results show that TAM can afford protection against brain mitochondrial injury promoted by several oxidative stress-related events, including the induction of the mitochondrial permeability transition pore. Since numerous neurodegenerative diseases are intimately related with mitochondrial dysfunction, the protective role of TAM seems worthy of further investigation to explore the potential therapeutical applications of this drug. However, the design of new therapeutical strategies should take into account the potential hepatotoxicity promoted by high doses of TAM.

\section{Acknowledgement}

This work was supported by FCT (Portuguese Research Council). Paula Moreira is the recipient of a grant SFRH/BD/5320/2001.

\section{References}

Barja, G., 1999. Mitochondrial oxygen radical generation and leak: sites of production in states 4 and 3, organ specificity, and relation to aging and longevity. J. Bioenerg. Biomembr. 31, 347-366.

Bernardi, P., Vassanelli, S., Veronese, P., Colonna, R., Szabo, I., Zoratti, M., 1992. Modulation of the mitochondrial permeability transition pore. Effect of protons and divalent cations. J. Biol. Chem. 267, 2934-2939.

Bossy-Wetzel, E., Green, D.R., 1999. Apoptosis: checkpoint at the mitochondrial frontier. Mutat. Res. 434, 243-251.

Brzyska, M., Bacia, A., Elbaum, D., 2001. Oxidative and hydrolytic properties of $\beta$-amyloid. Eur. J. Biochem. 268, 3443-3454.

Cadenas, E., Davies, K.J.A., 2000. Mitochondrial free radical generation, oxidative stress and aging. Free Radic. Biol. Med. 29, 222-230.

Cardoso, C.M.P., Custódio, J.B.A., Almeida, L.M., Moreno, A.J.M., 2001. Mechanisms of the deleterious effects of tamoxifen on mitochondrial respiration rate and phosphorylation efficiency. Toxicol. Appl. Pharmacol. 176, 145-152.

Cardoso, C.M.P., Almeida, L.M., Custódio, J.B.A., 2002a. 4-Hydroxytamoxifen is a potent inhibitor of the mitochondrial permeability transition. Mitochondrion 1, 485-495.

Cardoso, C.M.P., Moreno, A.J.M., Almeida, L.M., Custódio, J.B.A., 2002b. 4-Hydroxytamoxifen induces slight uncoupling of mitochondrial oxidative phosphorylation system in relation to the deleterious effects of tamoxifen. Toxicology 179, 221-232.

Chernyak, B.V., Bernardi, P., 1996. The mitochondrial permeability transition pore is modulated by oxidative agents through both pyridine nucleotides and glutathione at two separate sites. Eur. J. Biochem. 238, 623-630.

Connern, C.P., Halestrap, A.P., 1996. Chaotropic agents and increased matrix volume enhance binding of mitochondrial cyclophilin to the inner mitochondrial membrane and sensitize the mitochondrial permeability transition to $\left[\mathrm{Ca}^{2+}\right]$. Biochemistry 35 , 8172-8180.

Custódio, J.B.A., Almeida, L.M., Madeira, V.M.C., 1991. A reliable and rapid procedure to estimate drug partitioning in biomembranes. Biochem. Biophys. Res. Commun. 176, 1079-1085.

Custódio, J.B.A., Almeida, L.M., Madeira, V.M.C., 1993. The active metabolite hydroxytamoxifen of the anticancer drug tamoxifen 
induces structural changes in membranes. Biochim. Biophys. Acta $1153,308-314$

Custódio, J.B.A., Dinis, T.C.P., Almeida, L.M., Madeira, V.M.C., 1994. Tamoxifen and hydroxytamoxifen as intramembraneous inhibitors of lipid peroxidation. Evidence for peroxyl radical scavenging activity. Biochem. Pharmacol. 47, 1989-1998.

Custódio, J.B.A., Moreno, A.J.M., Wallace, K.B., 1998. Tamoxifen inhibits induction of the mitochondrial permeability transition by $\mathrm{Ca}^{2+}$ and inorganic phosphate. Toxicol. Appl. Pharmacol. 152, 5384-5394.

Dinis, T.C., Madeira, V.M.C., Almeida, L., 1994. Action of phenolic derivatives (acetominophen, salicylate, and 5-aminosalicylate) as inhibitors of membrane lipid peroxidation and as peroxyl radical scavengers. Arch. Biochem. Biophys. 315, 166-174.

Dubey, R.K., Tyurina, Y.Y., Tyurin, V.A., Gillespie, D.G., Branch, R.A., Jackson, E.K., Kagan, V.E., 1999. Estrogen and tamoxifen metabolites protect smooth muscle cell membrane phospholipids against peroxidation and inhibit cell growth. Circ. Res. 84, 229239.

Duthie, S.J., Melvin, W.T., Burke, M.D., 1995. Drug toxicity mechanisms in human hepatoma HepG2 cells: cyclosporin A and tamoxifen. Xenobiotica 25, 1151-1164.

Dubinsky, J.M., Levi, Y., 1998. Calcium-induced activation of the mitochondrial permeability transition in hippocampal neurons. J. Neurosci. Res. 53, 728-741.

Ernster, L., Nordenbrand, K., 1967. Microsomal lipid peroxidation. Methods Enzymol. 10, 574-580.

Estabrook, R.E., 1967. Mitochondrial respiratory control and the polarographic measurement of ADP/O ratios. Methods Enzymol. 10, 41-47.

Feng, Y., Fratkins, J.D., LeBlanc, M.H., 2004. Treatment with tamoxifen reduces hypoxic-ischemic brain injury in neonatal rats. Eur. J. Pharmacol. 484, 65-74.

Fiskum, G., Murphy, A.N., Beal, M.F., 1999. Mitochondria in neurodegeneration: acute ischemia and chronic neurodegenerative diseases. J. Cereb. Blood Flow Metab. 19, 351-369.

Fromson, J.M., Pearson, S., Bramah, S., 1973. The metabolism of tamoxifen (I.C.I. 46,474). II. In female patients. Xenobiotica 3, $711-714$.

Gornall, A.G., Bardawill, C.J., David, M.M., 1949. Determination of serum proteins by means of the biuret reaction. J. Biol. Chem. 177, 751-766.

Green, P.S., Bishop, J., Simpkins, J.W., 1997. 17 Alpha-estradiol exerts neuroprotective effects on SK-N-SH cells. J. Neurosci. 17, 511-515.

Hardy, J.A., Higgins, G.A., 1992. Alzheimer's disease: the amyloid cascade hypothesis. Science 256, 184-185.

Hissin, P.J., Hilf, R., 1976. A fluorometric method for determination of oxidized and reduced glutathione in tissues. Anal. Biochem. 74, 214-226.

Hoyt, K.R., McLaughlin, B.A., Higgins Jr., D.S., Reynolds, I.J., 2000. Inhibition of glutamate-induced mitochondrial depolarization by tamoxifen in cultured neurons. J. Pharmacol. Exp. Ther. 293, 480486.

Huang, X., Atwood, C.S., Hartshorn, M.A., Multhaup, G., Goldstein, L.E., Scarpa, R.C., Cuajungco, M.P., Gray, D.N., Lim, J., Moir, R.D., Tanzi, R.E., Bush, A.I., 1999. The A $\beta$ peptide of Alzheimer's disease directly produces hydrogen peroxide through metal ion reduction. Biochemistry 38, 76097616.

Jordan, V.C., Bamj, R.R., Brown, R.R., Gosdon, B., Santos, M.A., 1983. Determination and pharmacology of a new hydroxylated metabolite of tamoxifen observed in patient sera during therapy for advanced breast cancer. Cancer Res. 43, 1446-1450.

Kamo, N., Muratsugu, M., Hongoh, R., Kobatake, V., 1979. Membrane potential of mitochondria measured with an electrode sensitive to tetraphenylphosphonium and relationship between proton electrochemical potential and phosphorylation potential in steady state. J. Membr. Biol. 49, 105-121.

Kim, K.J., Jang, Y.Y., Han, E.S., Lee, C.S., 1999. Modulation of brain mitochondrial membrane permeability and synaptosomal $\mathrm{Ca}^{2+}$ transport by dopamine oxidation. Mol. Cell. Biochem. 201, 89-98.

Kimelberg, H.K., Jin, Y., Charniga, C., Feustel, P.J., 2003. Neuroprotective activity of tamoxifen in permanent focal ischemia. J. Neurosurg. 99, 138-142.

Kowaltowski, A.J., Netto, L.E., Vercesi, A.E., 1998. The thiol-specific antioxidant enzyme prevents mitochondrial permeability transition. Evidence for the participation of reactive oxygen species in this mechanism. J. Biol. Chem. 273, 12766-12769.

Kristián, T., Gertsch, J., Bates, T.E., Siesjö, B.K., 2000. Characteristics of the calcium triggered mitochondrial permeability transition in nonsynaptic brain mitochondria: effect of cyclosporin A and ubiquinone 0. J. Neurochem. 74, 1999-2009.

Kuo, Y.M., Chen, H.H., Shieh, C.C., Chung, K.P., Cherng, C.G., Yu, L., 2003. 4-Hydroxytamoxifen attenuates methamphetamine induced nigrostriatal dopaminergic toxicity in intact and gonadetomized mice. J. Neurochem. 87, 1436-1443.

Le Quoc, D., Le Quoc, K., Gaudemer, Y., 1976. Energy-dependent variation of thiol groups reactivity or accessibility in rat liver mitochondria, revealed by measurements of labelled thiol reagents incorporation. Biochem. Biophys. Res. Commun. 68, 106-113.

Lei, D.L., Long, J.M., Hengemihle, J., O’Neill, J., Manaye, K.F., Ingram, D.K., Mouton, P.R., 2003. Effects of estrogen and raloxifene on neuroglia number and morphology in the hippocampus of aged female mice. Neuroscience 121, 659-666.

Levesque, D., Di Paolo, T., 1993. Modulation by estradiol and progesterone of the GTP effect on striatal D-2 dopamine receptors. Biochem. Pharmacol. 45, 723-733.

Lien, E.A., Wester, K., Lonning, P.E., Solheim, E., Ueland, P.M., 1991. Distribution of tamoxifen and metabolites into brain tissue and brain metastases in breast cancer patients. Br. J. Cancer 63 , 641-645.

Macho, A., Hirsch, T., Marzo, I., Marchetti, P., Dallaporta, B., Susin, S.A., Zamzami, N., Kroemer, G., 1997. Glutathione depletion is an early and calcium elevation is a late event of thymocyte apoptosis. J. Immunol. 158, 4612-4619.

Mehta, S.H., Dhandapani, K.M., De Sevilla, L.M., Webb, R.C., Mahesh, V.B., Brann, D.W., 2003. Tamoxifen, a selective estrogen receptor modulator, reduces ischemic damage caused by middle cerebral artery occlusion in the ovariectomized female rat. Neuroendocrinology 77, 44-50.

Meister, A., Anderson, M.E., 1983. Glutathione. Annu. Rev. Biochem. 52, 711-760.

Morkuniene, R., Jekabsone, A., Borutaite, V., 2002. Estrogens prevent calcium-induced release of cytochrome $c$ from heart mitochondria. FEBS Lett. 521, 53-56.

Moreira, P.I., Custodio, J.B., Oliveira, C.R., Santos, M.S., 2004. Hydroxytamoxifen protects against oxidative stress in brain mitochondria. Biochem. Pharmacol. 68, 195-204.

Moreira, P.I., Santos, M.S., Moreno, A., Rego, A.C., Oliveira, C., 2002. Effect of amyloid beta-peptide on permeability transition pore: a comparative study. J. Neurosci. Res. 69, 257-267.

Moreno, A.J.M., Madeira, V.M.C., 1991. Mitochondrial bioenergetics as affected by DTT. Biochem. Biophys. Acta 1060, 166-174.

Murphy, A.N., Bredesen, D.E., Cortopassi, G., Wang, E., Fiskum, G., 1996. Bcl-2 potentiates the maximal calcium uptake capacity of neuronal cell mitochondria. Proc. Natl Acad. Sci. U.S.A. 93, 9893 9898.

Obata, T., 2002. Environmental estrogen-like chemicals and hydroxyl radicals induced by MPT in the striatum: a review. Neurochem. Res. 27, 423-431.

O’Neill, K.J., Brinton, R.D., 2002. Tamoxifen attenuates glutamate and estrogen - potentiated calcium signaling in hippocampal 
neurons. Program No.272.10 Abstract Viewer/Itinerary Planner,. Society for Neuroscience, Washington, DC, (CD-ROM).

O'Neill, K., Chen, S., Brinton, R.D., 2004. Impact of the selective estrogen receptor modulator, raloxifene, on neuronal survival and outgrowth following toxic insults associated with aging and Alzheimer's disease. Exp. Neurol. 185, 63-80.

Richardson, D.N., 1988. The history of Nolvadex. Drug Des. Deliv. 3, $1-14$.

Riddles, P.W., Blakeley, R.L., Zerner, B., 1983. Reassessment of Ellman's reagent. Methods Enzymol. 91, 49-60.

Rosenthal, R.E., Hamud, F., Fiskum, G., Varghese, P.J., Sharpe, S., 1987. Cerebral ischemia and reperfusion: prevention of brain mitochondrial injury by lidoflazine. J. Cereb. Blood Flow Metab. 7, $752-758$.

Simpson, P.B., Woollacott, A.J., Moneer, Z., Rand, V., Seabrook, G.R., 2002. Estrogen receptor ligand affect mitochondrial activity SH-SY5Y human neuroblastoma cells. Neuroreport 13, 957-960.

Tuquet, C., Dupont, J., Mesneau, A., Roussaux, J., 2000. Effects of tamoxifen on the electron transport chain of isolated rat liver mitochondria. Cell. Biol. Toxicol. 16, 207-219.

Wiseman, H., Laughton, M.J., Arnstein, H.R.V., Cannon, M., Halliwell, B., 1990. The antioxidant action of tamoxifen and its metabolites. Inhibition of lipoperoxidation. FEBS Lett. 236, 192-194.

Wiseman, H., Paganga, G., Rice-Evans, C., Halliwell, B., 1993. Protective actions of tamoxifen and 4-OH-tamoxifen against oxidative damage to human low-density lipoproteins: a mechanism accounting for the cardioprotective action of tamoxifen. Biochem. J. 292, 635-638.

Zoratti, M., Szabo, I., 1995. The mitochondrial permeability transition. Biochem. Biophys. Acta 1241, 139-176. 